\title{
Application of ashes as filling in reprocessed polypropylene: thermomechanical properties of composites
}

\author{
Lina Marcela Crespo ${ }^{1}$ and Carolina Caicedo ${ }^{1,2 *}$ \\ 1 Grupo de Investigación en Desarrollo de Materiales y Productos - GIDEMP, Centro Nacional de Asistencia \\ Técnica a la Industria - ASTIN, Servicio Nacional de Aprendizaje - SENA, Cali, Valle del Cauca, Colombia \\ ${ }^{2}$ Consejo Nacional de Ciencia y Tecnología - CONACYT, Consorcio de Investigación y de Innovación del \\ Estado de Tlaxcala, Centro de Investigación en Química Aplicada, Saltillo, Coahuila, México \\ *carolina.caicedo@conacyt.mx
}

\begin{abstract}
The life cycle of a product depends to a great extent on its reuse and ease of recycling. This work had developed of composite materials of reprocessed polypropylene composites with rice husk ash (RHA) and sugarcane bagasse ash (SBA) through the coextrusion and injection processes as main purpose. The polymeric matrix was reprocesed until six generations by the injection technique. The reprocessed PP was mixed in 80:20 proportions with respect to filler mineral, using maleic anhydride as coupling agent in a coextrusion machine. The new series of composite materials were analyzed thermal, mechanical, rheological and morphologically. The incorporation of ashes in the PP matrix achieved characteristics of improved tensile strength, conserving the thermal properties. For this reason, this work presents an alternative for the manufacture of composite materials from post-industrial waste.
\end{abstract}

Keywords: rheological analysis, rice husk ash, sugarcane bagasse ash, mechanical properties, thermal properties.

How to cite: Crespo, L. M., \& Caicedo, C. (2019). Application of ashes as filling in reprocessed polypropylene: thermomechanical properties of composites. Polímeros: Ciência e Tecnologia, 29(1), e2019003. https://doi. org/10.1590/0104-1428.02018

\section{Introduction}

In the last decade, researchers have been interested in reuse of organic and inorganic materials to be incorporated as filler in polymer matrices controlling aspects of shape, concentration and interface which get to contribute efficiently to the improvement of physicmechanical properties of the resulting composite material ${ }^{[1,2]}$. This practice is industrially known because of the reduction of cost in production. In general, the addition of filler mineral on the polymers decreases the impact energy, however, a weak interaction contributes to the fragmentation of it, due to the irregular flow of stresses which it is produced ${ }^{[3]}$. In fact, most studies on modification of semicrystalline polymers with rigid particles indicate a significant loss of tenacity in comparison with pure polymer ${ }^{[4]}$. In the development of composite materials, it has been found that isotactic polypropylene (PP) has been used in investigations, despite the inconvenience related to low impact resistance ${ }^{[5-7]}$. In the case of PP copolymers, the formation of covalent bonds between the PP matrix and the elastomer phase (rich in ethylene) avoiding the separation of the macroscopic phases. This elastomeric microdispersion phase can modify the mechanisms of plastic deformation of the PP matrix in such a way as to obtain high impact resistance ${ }^{[8]}$.

Rigid particles must be separated and create a free volume in the blend in a submicronic size level, which it is explained with the mechanism of cavitation in the hardened rubber systems ${ }^{[9]}$. Through time, the fillers most commonly used in polypropylene have been calcium carbonate and talc ${ }^{[10-12]}$, however, currently it continues being studied alternatives for the use of inorganic fillers from physic-chemical, thermal or biological degradation of agricultural residues as the case of ashes ${ }^{[13]}$. Rice husk is one of the main products of agricultural waste, according to statistics of FAO, rice global production was approximately of 756.7 millions tons in 2017 , moreover, a production of 989.96 tons were reported by DANE in Colombia in the first half of $2017^{[14]}$. Therefore, the rice husk is a derivative of great interest for researchers and producers due to the challenge it means the offering alternative materials which generate added value to this residue.

The literature reports a series of studies about polymer composites and rice husk ${ }^{[15,16]}$, one of the favorite fillings after palm oil and rubber, as well as; the product of incineration: Rice husk ash (RHA) compound mainly by silica between $87-89 \%{ }^{[1,17,18]}$. Some results show an $18 \%$ increase in mechanical strength and elongation to break of high density polyetilene (HDPE) composites with RHA incorporated at $1.5 \%$ in weight in presence of maleic anhydride as coupling agent ${ }^{[19]}$. In other research, it was obtained the improvement of the stress modulus in composites of white rice husk ash 
(WRHA) with polypropylene (PP)/natural rubber, however, tensile strength, elongation to break decreased with increasing the filler of WRHA, while the incorporation of the coupling agent (Silane, 2-aminopropyl triethoxysilane), reduced the amount of absorbed water by the composite material ${ }^{[20]}$. On the other hand, some proposals have been presented to redirect the use of sugar cane industry waste through the implementation of husk ash as reinforcement in rubber, and the results are promising, an increase of $300 \%$ in the stress modulus was presented ${ }^{[21]}$. Therefore, in this work we proposed obtaining two series of composite materials from recovered PP copolymer random with fillers mineral of Rice Husk Ash (RHA) and Sugarcane Bagasse Ash (SBA), due to the above, to know the influence that presented by incorporation of particulate inorganic material in the different generations of the PP on the physic properties of

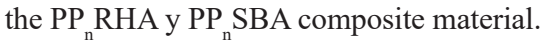

\section{Materials and Methods}

\subsection{Materials}

Polypropylene copolymer random was used (PP) 02R01CA-1 produced by Propilco with a melt flow index (MFI) equal to $1.6 \mathrm{dg} / 10 \mathrm{~min}\left(230^{\circ} \mathrm{C}, 2.16 \mathrm{~kg}\right)$, the coupling agent used was modified polypropylene with licocene PP-g-MA 7452 from Clariant, presenting an addition of 7\% maleic anhydride, $156{ }^{\circ} \mathrm{C}$ melting point, $0.91 \mathrm{~g} / \mathrm{cm}^{3}$ density and high crystallinity. The ashes of rice husk and sugarcane bagasse ash were from a rice mill and a sugar mill in Valle del Cauca, respectively. The granulometric characteristics are presented in Table 1.

\subsection{Preparation of composites}

Multiple injection (six successive) were carried out either on DEMAG injection machine 150 tons model 1991, hydraulic and insertable valves. The temperature profile

Table 1. Granulometric characteristics of rice husk ash (RHA) and sugarcane bagasse ash (SBA).

\begin{tabular}{ccc}
\hline Types of Ashes & RHA & SBA \\
\hline \#Sieve & Retained $(\%)$ & Retained $(\%)$ \\
50 & 0.00 & 0.29 \\
100 & 0.10 & 9.87 \\
140 & 1.20 & 36.99 \\
200 & 11.43 & 40.38 \\
325 & 53.06 & 12.09 \\
400 & 18.86 & 0.07 \\
Fondo & 15.35 & 0.29 \\
Average particle size $(\mu \mathrm{m})$ & $63 \pm 15$ & $106 \pm 37.5$ \\
\hline
\end{tabular}

was $190{ }^{\circ} \mathrm{C}-195^{\circ} \mathrm{C}-195^{\circ} \mathrm{C}$ and $200{ }^{\circ} \mathrm{C}$ for the nozzle. The injection pressure was kept constant at $75.6 \mathrm{~b}$, The mold was kept at $45^{\circ} \mathrm{C}$ by a water cooling system and a constant injection speed of $45 \mathrm{~cm}^{3} \cdot \mathrm{s}^{-1}$ was applied. The injection parameters were kept constant in each cycle. The specimens obtained by injection were type $1 \mathrm{~b}$ "dogbone" according to ISO 527-2 (step 2 or 3). Then, a part of the test pieces was passed through a Rotrogram Mold-tek blade mill at $1745 \mathrm{rpm}$, where granules with a diameter of $\sim 8 \mathrm{~mm}$ were obtained. The processing methodology is summarized in Figure 1 and the successive stages are detailed.

The composite materials were mixed in a double-screw extruder model Haake Rheomex OS PTW in co-rotating parallel configuration. The temperature profile with gradual increase of $5{ }^{\circ} \mathrm{C}$ from $155^{\circ} \mathrm{C}$ to $200{ }^{\circ} \mathrm{C}$, at the end of the screws, divided into 10 cylinder zones, each zone covering a length of 4D. Finally, the composites were injected and molded under the same conditions as the material reprocessing. The samples were differentiated for the next symbol $\mathrm{PP}_{\mathrm{n}} \mathrm{RHA}$ and $\mathrm{PP}_{\mathrm{n}} \mathrm{SBA}$, where PP indicates the used matrix of polypropylene, RHA and SBA the incorporated mineral fillers (RHA: rice husk ash, SBA: sugarcane bagasse ash), $\mathrm{n}$ subscript corresponds to reprocessing cycle number.

\subsection{Thermogravimetric Analysis (TGA) and Differential Scanning Calorimetry (DSC)}

The thermal properties were determined in a thermogravimetric TGA/DSC 2 STAR System, Mettler Toledo. The samples $(10 \pm 0.5 \mathrm{mg})$ were put in alumina crucibles in a temperature range between $25^{\circ} \mathrm{C}$ to $\sim 500{ }^{\circ} \mathrm{C}$ under nitrogen atmosphere $\left(50 \mathrm{~cm}^{3} / \mathrm{min}\right)$ with a heating rate of $10^{\circ} \mathrm{C} / \mathrm{min}$. It was worked out according to the ASTM E1131-98 and ASTM D3418-12 standards, respectively.

\subsection{Tensile and flexural properties}

The mechanical property measures were done in a universal Goodbrand machine according with the ASTM D638 standard, with a test speed of $50 \mathrm{~mm} / \mathrm{min}$ and a load cell of $500 \mathrm{kgf}$. The enlargement values were determined (by extension of the jaws) to the tearing and tensions resistance. The environmental chamber Dies, a Baker caliper gauge and an Oakton thermohygrometer. The flexural tests were performed in Goodbrand machine according to the ASTM D790-10 standard, with a test speed of $5 \mathrm{~mm} / \mathrm{min}$ and a $50 \mathrm{kgf}$ cell. Modules, resistances and elongation percentages were obtained. Five samples were analyzed for every composites mix and the average values are presented.

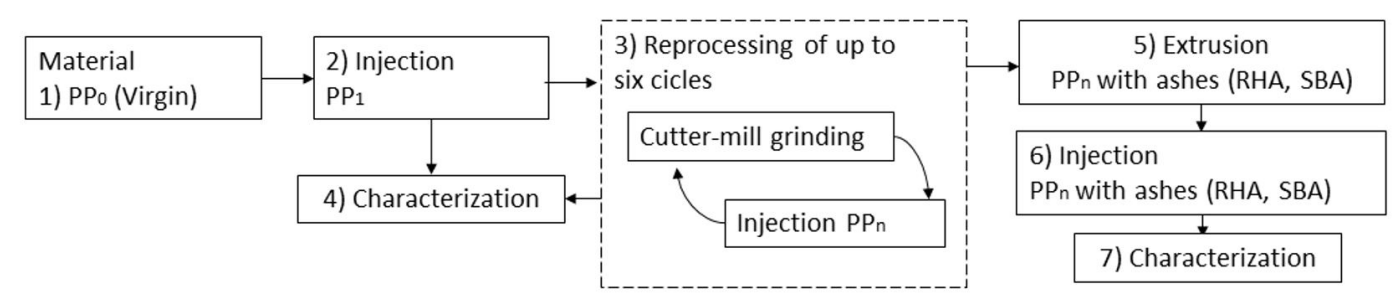

Figure 1. Stages for process of obtaining composites and composite material development. 


\subsection{Microstructural analysis}

The development of compounds were analyzed through scanning electron microscopy (SEM). Usign an SEM JEOL de Mesa JCM 50000. For the filler particles analysis within the composites, cross-section samples of composites were prepared through the same methodology. They were obtained from the middle part of the dog-bone samples. Then, they were submitted to a gold coverage using PVD, in a high vacuum and a $5 \mathrm{kV}$ voltage was used. The magnifications were $\mathrm{x} 44$ to determine the dispersion, $\mathrm{x} 200$ to asses the general morphology of the particles and in order to observe the ash/matrix interface. It is worth to mention, that for every analysis the sample were conditioned to $25^{\circ} \mathrm{C}$ in an environment of relative humidity of $50 \pm 5 \%$ during $48 \mathrm{~h}$.

\subsection{Rheological analysis}

The rheological measurements were performed at $190^{\circ} \mathrm{C}$ and the shear rate was in the range of 0.001 to $300 \mathrm{~s}^{-1}$. The dynamo-mechanical tests settings were: the percentage of deformation between 1 and $10 \%$, with a frequency range of 0.1 to $628.10 \mathrm{rad} / \mathrm{s}$, to determine the storage modulus and the loss modulus.

\section{Results and Discussions}

\subsection{Thermal analysis}

The results obtained from the curves of thermogravimetric analysis (TGA) and differencial scanning calorimetry (DSC) are shown in the Table 2, which indicates in every cases that initial degradation for generations 1, 3 and 6 of $\mathrm{PP}$ and developed composite materials ( $\mathrm{PP}_{\mathrm{n}} \mathrm{RHA}$ and $\left.\mathrm{PP}_{\mathrm{n}} \mathrm{SBA}\right)$ are fewer than required temperature to transform them under the process of injection and extrusion, without exceeding $200^{\circ} \mathrm{C}$, as a result, the integrity of the reference reprocessed materials and the blend of composite material is guaranteed. In addition, the temperatures and fusion enthalpy were evaluated.

In the Table 2 it is shown that fusion temperatures of composite materials $\mathrm{PP}_{\mathrm{n}} \mathrm{RHA}$ y $\mathrm{PP}_{\mathrm{n}} \mathrm{SBA}$ remained in values of $147^{\circ} \mathrm{C}$; this in comparison with the two departure reprocessed materials of PP. The temperatures of initial degradation presente a more pronounced increase of $\mathrm{PP}_{n} \mathrm{SBA}$, which it evinces the influence of ashes in absortion of the heat generated in the degradation processes, producing a deceleration of itself ${ }^{[22,23]}$. This behavior is also attributed to a set of characteristics produced by the presence of ashes in composite materials of the polymeric matrix, within them it is possible to find the effect that inorganic ashes have as nucleating agent, causing a foretaste in the beginning of crystallization of PP. Besides, the limitation in mobility of the polymeric chains which get to delay the volatilization of the generated products in the temperature in which occurs the break of the carbon-carbon junctions ${ }^{[18,22]}$.

\subsection{Mechanical properties}

\subsubsection{Flexural and stress resistance}

In Table 3 can be found the results of maximum resistance obtained for the reprocessed materials until the sixth cycle, which refer to a stable behavior with an average value of $25.38 \pm 1.40 \mathrm{MPa}$.
The results of the tensile test for the sample of $\mathrm{PP}_{\mathrm{n}} \mathrm{RHA}$ and $\mathrm{PP}_{\mathrm{n}} \mathrm{SBA}$ composite samples are presented in Table 4, where the conservation of the properties is appreciated, which is attributed to the good dispersion of the particles within the matrix by the presence of the coupling agent (PP-g-MA) which in turn it facilitates the transfer of properties between both materials, allowing the ash particles which present high stiffness to generate difficulty in the deformation of composites, making them less ductile ${ }^{[24]}$. This way, the addition of ashes to PP lead to the increses of stiffness with values over to $50 \%$ in composite materials with respect to the reprocessed starting materials (see Table 3 ) ${ }^{[25]}$. The stiffness in the $\mathrm{PP}_{\mathrm{n}} \mathrm{SBA}$ was more notorious in a $25 \%$ than the $\mathrm{PP}_{\mathrm{n}} \mathrm{RHA}$.

Table 5 shows an increase $(\sim 10 \%)$ for the values of maximum stress obtained by the flexural test for $\mathrm{PP}_{n} \mathrm{RHA}$ and $\mathrm{PP}_{\mathrm{n}} \mathrm{SBA}$ in relation to the PP resin. On the other hand,

Table 2. Result of TGA and DSC obtained for the processed polypropylene and composed materials of RHA and SBA.

\begin{tabular}{cccc}
\hline \multirow{2}{*}{ Sample } & \multicolumn{3}{c}{ Temperatures } \\
\cline { 2 - 4 } & $\mathbf{T}_{\mathbf{i}}$ & $\mathbf{T}_{\max }$ & $\mathbf{T}_{\mathbf{m}}$ \\
\hline $\mathrm{PP}_{1}$ & 239.4 & 436.2 & 149.1 \\
$\mathrm{PP}_{3}$ & 231.2 & 428.9 & 147.5 \\
$\mathrm{PP}_{6}$ & 229.0 & 429.8 & 146.5 \\
$\mathrm{PP}_{1} \mathrm{RHA}$ & 219.5 & 423.1 & 145.4 \\
$\mathrm{PP}_{3} \mathrm{RHA}$ & 229.1 & 390.3 & 145.8 \\
$\mathrm{PP}_{6} \mathrm{RHA}$ & 229.9 & 415.5 & 146.7 \\
$\mathrm{PP}_{1} \mathrm{SBA}$ & 233.2 & 413.1 & 143.7 \\
$\mathrm{PP}_{3} \mathrm{SBA}$ & 241.4 & 428.9 & 146.1 \\
$\mathrm{PP}_{6} \mathrm{SBA}$ & 249.0 & 456.5 & 146.7 \\
\hline
\end{tabular}

$\mathrm{T}_{\mathrm{i}}=$ Temperature of initial degradation; $\mathrm{T}_{\max }=$ Temperature of maximum degradation; $\mathrm{T}_{\mathrm{m}}=$ Melting temperature.

Table 3. Characterization of the mechanical properties of the matrix of reprocessed polypropylene.

\begin{tabular}{ccccccc}
\hline \multirow{3}{*}{$\begin{array}{c}\text { Sample } \\
\mathbf{P P}\end{array}$} & $\begin{array}{c}\text { Ultimate } \\
\text { stress } \\
\mathbf{( M P a )}\end{array}$ & $\begin{array}{c}\text { Fracture } \\
\text { stress } \\
\mathbf{( M P a )}\end{array}$ & $\begin{array}{c}\text { Strain } \\
\mathbf{( \% )}\end{array}$ & & $\begin{array}{c}\text { Ultimate } \\
\text { stress } \\
(\mathbf{M P a})\end{array}$ & $\begin{array}{c}\text { Fracture } \\
\text { stress } \\
(\mathbf{M P a})\end{array}$ \\
\hline $\mathrm{PP}_{1}$ & $25.46 \pm 0.21$ & $16.59 \pm 0.23$ & $85.04 \pm 3.58$ & & $0.99 \pm 0.04$ & $2.16 \pm 0.12$ \\
$\mathrm{PP}_{3}$ & $23.95 \pm 0.51$ & $15.95 \pm 0.23$ & $132.75 \pm 1.34$ & $0.97 \pm 0.04$ & $2.45 \pm 0.21$ \\
$\mathrm{PP}_{6}$ & $26.74 \pm 0.38$ & $17.47 \pm 0.24$ & $130.12 \pm 0.41$ & $1.05 \pm 0.01$ & $2.73 \pm 0.33$ \\
\hline
\end{tabular}

$\mathrm{MPa}=$ Megapascals.

Table 4. Results of the tests of stress of the composite materials with ashes.

\begin{tabular}{cccc}
\hline Sample & $\begin{array}{c}\text { Ultimate } \\
\text { stress (MPa) }\end{array}$ & $\begin{array}{c}\text { Fracture } \\
\text { Stress (MPa) }\end{array}$ & $\begin{array}{c}\text { Strain } \\
\mathbf{( \% )}\end{array}$ \\
\hline $\mathrm{PP}_{1} \mathrm{RHA}$ & $22.66 \pm 0.71$ & $15.88 \pm 0.50$ & $46.86 \pm 3.99$ \\
$\mathrm{PP}_{3} \mathrm{RHA}$ & $24.07 \pm 0.10$ & $15.90 \pm 0.44$ & $48.82 \pm 1.24$ \\
$\mathrm{PP}_{6} \mathrm{RHA}$ & $24.91 \pm 0.04$ & $16.23 \pm 0.33$ & $49.97 \pm 2.45$ \\
$\mathrm{PP}_{1} \mathrm{SBA}$ & $25.28 \pm 0.71$ & $21.39 \pm 1.00$ & $19.29 \pm 0.75$ \\
$\mathrm{PP}_{3} \mathrm{SBA}$ & $25.03 \pm 0.34$ & $23.25 \pm 0.76$ & $18.20 \pm 0.84$ \\
$\mathrm{PP}_{6} \mathrm{SBA}$ & $26.342 \pm 0.09$ & $23.16 \pm 0.30$ & $18.47 \pm 0.67$ \\
\hline
\end{tabular}

$\mathrm{MPa}=$ Megapascals. 
the modulus of elasticity for the compounds with the highest number of reprocesses decreases by $50 \%$. These results present a relation with the stress results previously explained.

\subsection{Microstructural analysis}

The SEM micrographs of the fracture surfaces of the polypropylene compounds with $20 \%$ by weight of the ashes are shown in Figure 2. It is clearly seen in these images that the ash particles were detached from the matrix (PP) in

Table 5. Results of the flexural tests of the composite materials with ashes.

\begin{tabular}{lcc}
\hline Sample & $\begin{array}{c}\text { Ultimate stress } \\
(\mathbf{M P a})\end{array}$ & $\begin{array}{c}\text { Fracture Stress } \\
(\mathbf{M P a})\end{array}$ \\
\hline PP $\mathrm{RHA}$ & $1.15 \pm 0.04$ & $2.45 \pm 0.21$ \\
$\mathrm{PP}_{3} \mathrm{RHA}$ & $1.10 \pm 0.02$ & $1.91 \pm 0.25$ \\
$\mathrm{PP}_{6} \mathrm{RHA}$ & $1.15 \pm 0.03$ & $1.70 \pm 0.22$ \\
$\mathrm{PP}_{1} \mathrm{SBA}$ & $1.21 \pm 0.02$ & $1.71 \pm 0.20$ \\
$\mathrm{PP}_{3} \mathrm{SBA}$ & $1.24 \pm 0.04$ & $1.40 \pm 0.18$ \\
$\mathrm{PP}_{6} \mathrm{SBA}$ & $1.22 \pm 0.03$ & $1.27 \pm 0.15$ \\
\hline
\end{tabular}

$\mathrm{MPa}=$ Megapascals. the material which underwent ductile tearing around these particles. When comparing the images of Figure $2 \mathrm{~b}$ and $2 \mathrm{c}$, it can be seen that the PP RHA composites exhibited a lower degree of ductile tearing of the filler present in the matrix, due to the presence of PP fibrils. The above is in agreement with the significant increase in the maximum effort found for PP SBA compounds. It should be mentioned that Figure 2c ( $\left.\mathrm{PP}_{6} \mathrm{SBA}\right)$ shows particles with a cenosphere morphology of fly ash ${ }^{[26]}$.

The Figure 3 shows a view furthest from the compounds that allows observing an increase in the concentration of fillers is greater in the center of the specimen, which can be evidenced by the presence of pores and agglomerates that with the increase of generations is less noticeable due to the easy dispersion of filler at low viscosity. These are responsible for facilitating the rupture at the time of stressing the material. The holes with measured lengths of 0.65 to $0.85 \mathrm{~mm}$ denote the presence of agglomerates. These are observed more exposed in the $\mathrm{PP}_{\mathrm{n}} \mathrm{SBA}$ resulting in rougher surfaces; while for $\mathrm{PP}_{\mathrm{n}} \mathrm{RHA}$ a behavior similar to the matrix is shown when generating short fibers.

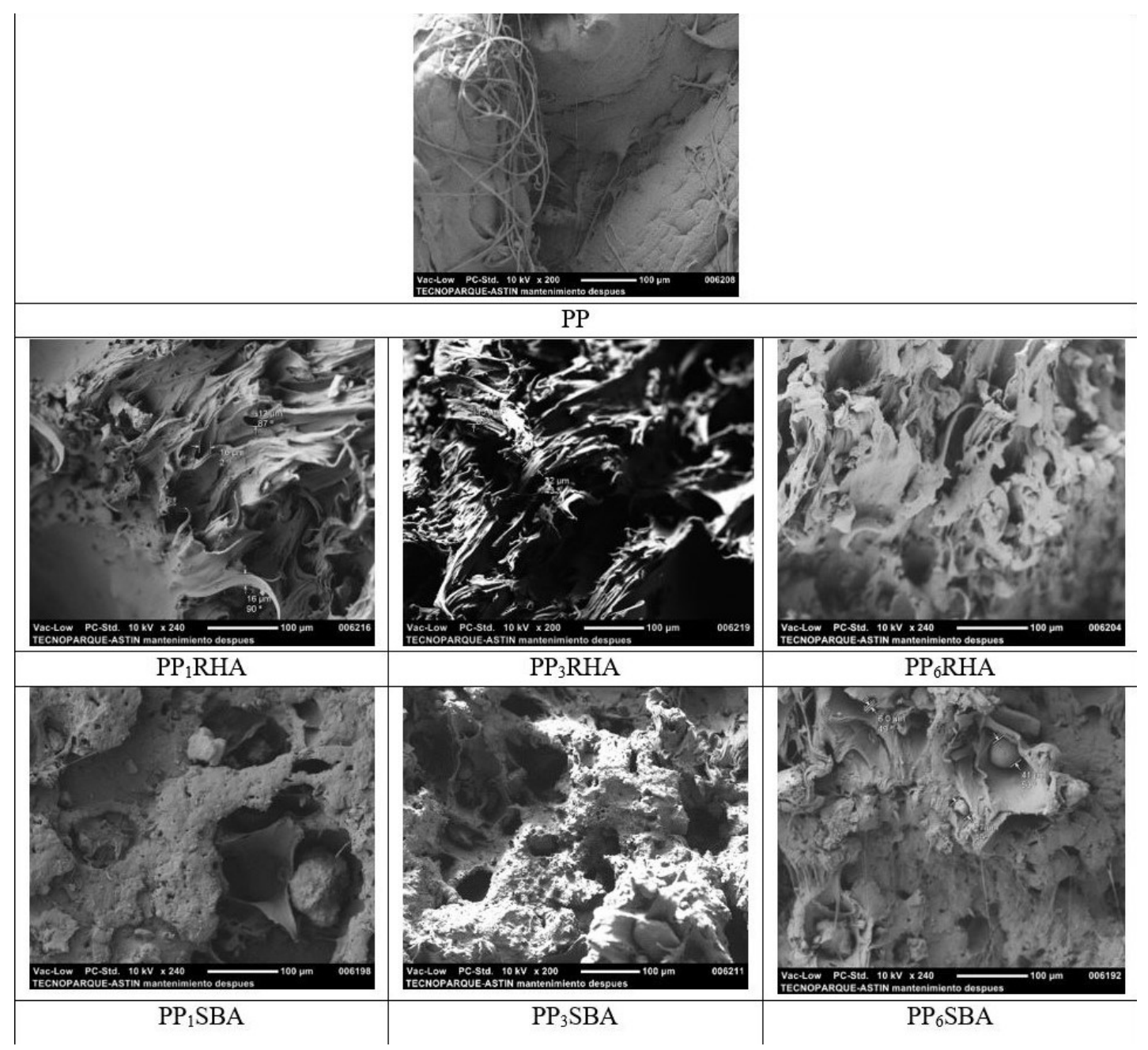

Figure 2. Micrographs obtained by SEM of $\mathrm{PP}_{\mathrm{n}} \mathrm{RHA}$ and $\mathrm{PP}_{\mathrm{n}} \mathrm{SBA}$ compounds at 200x magnification. 


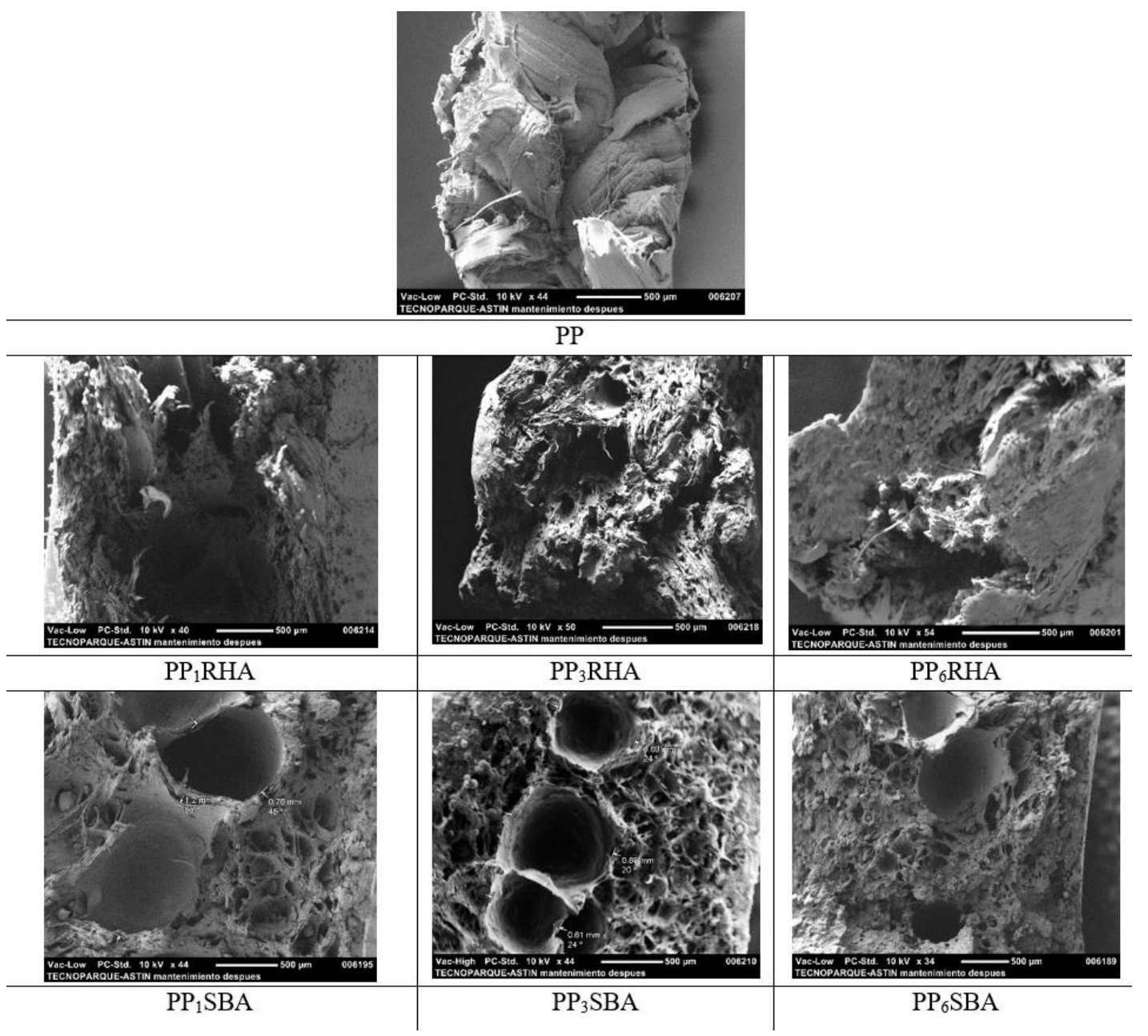

Figure 3. Micrographs obtained by SEM of $\mathrm{PP}_{n}$ RHA and $\mathrm{PP}_{n}$ SBA compounds at $44 \mathrm{x}$ magnification.

\subsection{Rheological analysis}

The complex viscosity values found for the compounds decrease as the matrix increases the number of reprocesses (Figure 4), this behavior is due to the degradation suffered by the polymer due to the temperature and mechanical stress demonstrated in a previous study ${ }^{[27]}$. In general, the fillers generate a strong shearing thinning effect, this dependence against frequency is less noticeable for the pure polymer. It is interesting to observe the influence of the type of charge in the viscosity curves at low frequencies, in this case, rice husk ash has a lower dispersion compared to sugarcane bagasse ash, keeping the trend of the matrix which in turn reflects a less stable behavior.

On the other hand, the curves corresponding to the storage and loss modules were analyzed as a function of the angular frequency for the PP and the composites with ashes, which are presented in Figure 5. These exhibit a directly proportional increase of the modules with respect to the angular frequency, similar behavior among the samples developed.

The Figure 5a shows in the frequency range studied, that the material between 10 and $51.05 \mathrm{rad} / \mathrm{s}$, has a viscous behavior as liquids, but at $51.05 \mathrm{rad} / \mathrm{s}$, the viscous to elastic

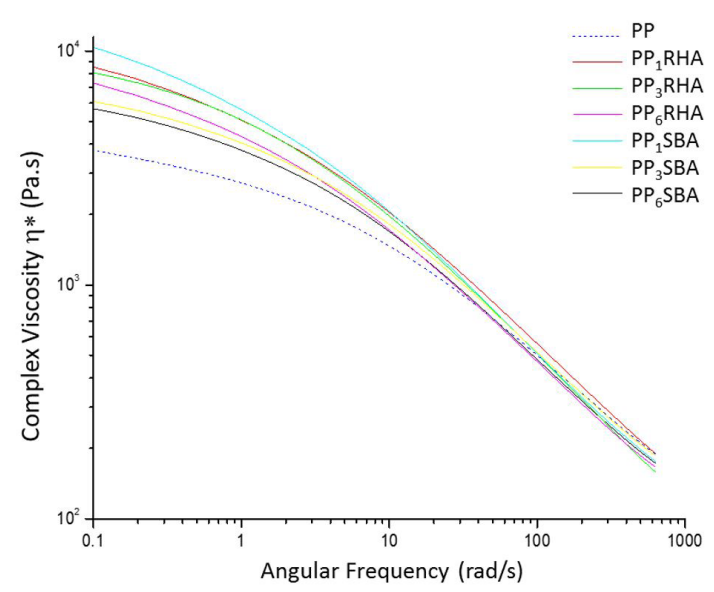

Figure 4. Complex viscosity of PP, $P_{n} R_{n} H A$ and $P_{n} S B A$.

transition occurs, since G'> G' (behaves like a solid), this behavior is typical of thermoplastic materials however for this material it is mainly elastic. In the Figure 5b, the PPRHA sample has the highest elastic behavior, since the transition 
a)

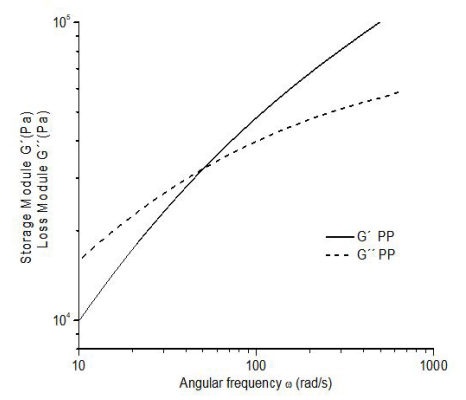

b)

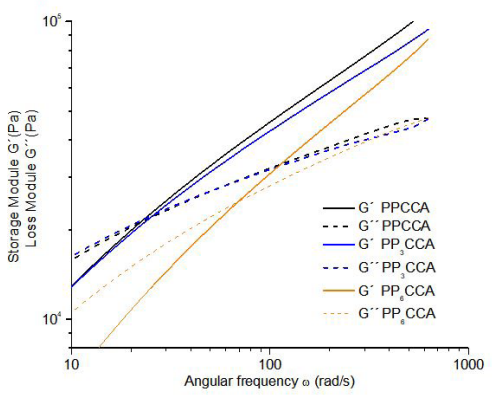

c)

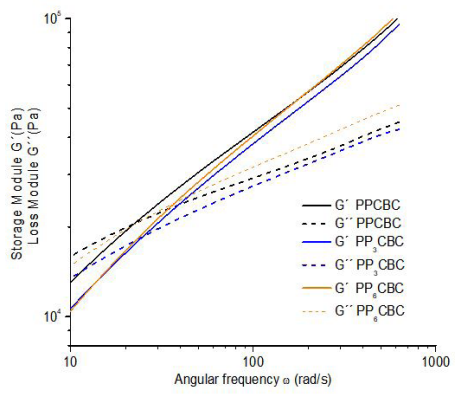

Figure 5. Storage and loss modules of (a) PP; (b) $P_{n}$ RHA; and (c) $P_{n}$ SBA.

from viscous to elastic ( $\left.G^{\prime}>G^{\prime \prime}\right)$ occurs at $21.24 \mathrm{rad} / \mathrm{s}$, the sample $\mathrm{PP}_{3} \mathrm{RHA}$, the sample $\mathrm{PP}_{3} \mathrm{RHA}$, follows in this order, since the viscous to elastic transition occurs at $25.51 \mathrm{rad} / \mathrm{s}$. The sample PP RHA has a higher viscous behavior, since the angular frequency at which G'> G' has a value of $69.37 \mathrm{rad} / \mathrm{s}$. These results denote a viscoelastic behavior. Finally, the PP 1 SBA sample of Figure 5c showed the highest elastic behavior, since the viscous to elastic transition was given at an angular frequency of $22.57 \mathrm{rad} / \mathrm{s}$, in the case of the samples $\mathrm{PP}_{3} \mathrm{SBA}$ and $\mathrm{PP}_{6} \mathrm{SBA}$ the angular frequency values a which occurred the transition were 37.53 and $25.08 \mathrm{rad} / \mathrm{s}$, respectively. This result indicates that the $\mathrm{PP}_{3} \mathrm{SBA}$ sample has the highest viscous behavior. In addition, the reprocessing of the material increases its fluidity, which may be due to a better dispersion or orientation of the reinforcer. An important aspect is that the sample reprocessed six times ( $\mathrm{PP}_{6} \mathrm{SBA}$ ), showed lower viscous behavior than the one processed 3 times ( $\left.\mathrm{PP}_{3} \mathrm{SBA}\right)$, due to a greater interaction of the reinforcing material with the $\mathrm{PP}$ than the $\mathrm{PP}_{3} \mathrm{SBA}$ sample. In addition, according to the results, no direct relationship of the viscoelastic behavior with the reprocessing number is observed. On the other hand, the polydispersity indices for the compounds were estimated with respect to the PP, which presents a value of 3.1 and values between 3.9 and 5.1 were found for $\mathrm{PP}_{6} \mathrm{RHA}$ and $\mathrm{PP}_{3} \mathrm{SBA}$, respectively. The above is indicative of the loss of crystallinity in these compounds.

\section{Conclusions}

The results obtained show that the use of post-industrial ashes from the production of rice and cane are promising for the development of composite materials, as well as, the use of recovered polymeric material (PP). The developed composite materials showed a stable behavior for the melting temperatures. The degradation temperatures showed more pronounced increases for the PPnSBA series. In the same way, in the mechanical results, the rigidity of the $\mathrm{PP}_{\mathrm{n}} \mathrm{SBA}$ composite materials was favored about $25 \%$ more than the PP ${ }_{n}$ RHA series. However, the filler of ash had an effect on the stiffness of the composite materials, this occurs as a consequence of the suitable dispersion generated by the coupling agent (PP-g-MA), which facilitated the transfer of the matrix to the fillers.

The images captured by SEM showed important characteristics that complemented the mechanical analysis, with this it is possible to conclude that the rice husk ash favor the modulus of elasticity with respect to those obtained with sugarcane bagasse ash with the presence of fibrils. The rupture caused in the tension test was favored by agglomerates of the filler and cenosphere particles for the case of the PP ${ }_{n}$ SBA compounds. The process used was adequate to disperse the reinforcing material, in the enlarged images the presence of pores and particles was observed homogeneously. In the rheological analysis, the angular frequency range that corresponds to the viscous to elastic behavior studied, it was found that the PP object of study is mainly elastic, while $\mathrm{PP}_{\mathrm{n}}$ RHA and $\mathrm{PP}_{\mathrm{n}} \mathrm{SBA}$ are viscoelastic. The reprocessing of the materials produced a greater fluidity of the mixtures, because the elastic behavior of the solids decrease with the reprocessing of the material and incorporation of the ashes, this possibly is due to a greater dispersion of the reinforcement or a smaller interaction of this with the matrix. In general, the storage module exceeded the loss module at lower frequencies for the compounds (between 20 and $30 \mathrm{rad} / \mathrm{s}$ ) compared to the PP (55 rad/s), which stand out the high viscosity of these compounds. The PP ${ }_{6}$ RHA sample, despite revealing elasticity conditions higher than $70 \mathrm{rad} / \mathrm{s}$, presents modules $25 \%$ lower than the PP.

\section{Acknowledgements}

The autors gratefully acknowledges the ASTIN-SENA, Research Group in Development of Materials and Products (GIDEMP by its Spanish acronym), Bio- $y$ Nano-technology line of Tecnoparque in 2017. Also, we thank the SENNOVA (projects SGPS-2195-2017) for financial support. C. C. acknowledges the economic support of the Program of Cátedras CONACYT from CONACyT-CIQA(2018-2028).

\section{References}

1. Arjmandi, R., Ismail, A., Hassan, A., \& Abu Bakar, A. (2017). Effects of ammonium polyphosphate content on mechanical, thermal and flammability properties of kenaf/polypropylene and rice husk/polypropylene composites. Construction \& Building Materials, 152, 484-493. http://dx.doi.org/10.1016/j. conbuildmat.2017.07.052.

2. Caicedo, C., Vázquez Arce, A., Crespo, L. M., De la Cruz, H., \& Ossa, Ó. H.. (2015). Material compuesto de matriz polipropileno (PP) y fibra de cedro: influencia del compatibilizante PPg-MA. Informador Técnico, 79(2), 118-126. http://dx.doi. org/10.23850/22565035.156. 
3. Carrillo-Escalante, H. J., Alvarez-Castillo, A., Valadez-Gonzalez, A., \& Herrera-Franco, P. J. (2016). Effect of fiber-matrix adhesion on the fracture behavior of a carbon fiber reinforced thermoplastic-modified epoxy matrix. Carbon Letters, 19(1), 47-56. http://dx.doi.org/10.5714/CL.2016.19.047.

4. Eftekhari, M., \& Fatemi, A. (2016). Creep-fatigue interaction and thermo-mechanical fatigue behaviors of thermoplastics and their composites. International Journal of Fatigue, 91, 136-148. http://dx.doi.org/10.1016/j.ijfatigue.2016.05.031.

5. Barczewski, M., Matykiewicz, D., Andrzejewski, J., \& Skorczewska, K. (2016). Application of waste bulk moulded composite (BMC) as a filler for isotactic polypropylene composites. Journal of Advanced Research, 7(3), 373-380. http://dx.doi.org/10.1016/j.jare.2016.01.001. PMid:27222742.

6. Zhao, S., Chen, F., Huang, Y., Dong, J. Y., \& Han, C. C. (2014). Crystallization behaviors in the isotactic polypropylene/ graphene composites. Polymer, 55(16), 4125-4135. http:// dx.doi.org/10.1016/j.polymer.2014.06.027.

7. Bandyopadhyay, J., Ray, S. S., Ojijo, V., \& Khoza, M. (2017). Development of a highly nucleated and dimensionally stable isotactic polypropylene/nanoclay composite using reactive blending. Polymer, 117, 37-47. http://dx.doi.org/10.1016/j. polymer.2017.04.013.

8. Mireya, M., Sánchez, J. J., Jiménez, M. C., Salas, L., Santana, O. O., Gordillo, A., Maspoch, M. L., \& Müller, A. J. (2005). Propiedades Mecánicas y Comportamiento a Fractura de un Polipropileno Homopolímero comparado con un Copolímero de impacto grado comercial. Revista Latinoamericana de Metalurgia y Materiales, 25(1-2), 31-45. Retrieved in 2018, March 14, from http://www.scielo.org.ve/scielo.php?script=sci arttext\&pid=S0255-69522005000100005\&lng=es\&tlng=es

9. Tang, L. C., Wang, X., Wan, Y. J., Wu, L. B., Jiang, J. X., \& Lai, G. Q. (2013). Mechanical properties and fracture behaviors of epoxy composites with multi-scale rubber particles. Materials Chemistry and Physics, 141(1), 333-342. http://dx.doi.org/10.1016/j.matchemphys.2013.05.018.

10. Essabir, H., Bensalah, M. O., Rodrigue, D., Bouhfid, R., \& Qaiss, A. (2017). A comparison between bio-and mineral calcium carbonate on the properties of polypropylene composites. Construction \& Building Materials, 134, 549-555. http:// dx.doi.org/10.1016/j.conbuildmat.2016.12.199.

11. Makhlouf, A., Satha, H., Frihi, D., Gherib, S., \& Seguela, R. (2016). Optimization of the crystallinity of polypropylene/ submicronic-talc composites: the role of filler ratio and cooling rate. Express Polymer Letters, 10(3), 237-247. http://dx.doi. org/10.3144/expresspolymlett.2016.22.

12. Caicedo, C., Vázquez-Arce, A., Ossa, O. H., De la Cruz, H., \& Maciel-Cerda, A. (2018). Physicomechanical behavior of composites of polypropylene, and mineral fillers with different process cycles. Dyna, 85(207), 260-268. http://dx.doi. org/10.15446/dyna.v85n207.71894.

13. Pongdong, W., Kummerlöwe, C., Vennemann, N., Thitithammawong, A., \& Nakason, C. (2018). A comparative study of rice husk ash and siliceous earth as reinforcing fillers in epoxidized natural rubber composites. Polymer Composites, 39(2), 414426. http://dx.doi.org/10.1002/pc.23951.

14. Organización de las Naciones Unidas para la Alimentación y la Agricultura - FAO. (2017). Seguimiento del mercado del arroz de la FAO (SMA). Rome: FAO. Retrieved in 2018, March 14, from http://www.fao.org/economic/est/publications/ publicaciones-sobre-el-arroz/seguimiento-del-mercado-delarroz-sma/es/

15. Rozman, H. D., Yeo, Y. S., Tay, G. S., \& Abubakar, A. (2003). The mechanical and physical properties of polyurethane composites based on rice husk and polyethylene glycol.
Polymer Testing, 22(6), 617-623. http://dx.doi.org/10.1016/ S0142-9418(02)00165-4.

16. Premalal, H. G., Ismail, H., \& Baharin, A. (2003). Effect of processing time on the tensile, morphological, and thermal properties of rice husk powder-filled polypropylene composites. Polymer-Plastics Technology and Engineering, 42(5), 827-851. http://dx.doi.org/10.1081/PPT-120024998.

17. Battegazzore, D., Bocchini, S., Alongi, J., \& Frache, A. (2014). Rice husk as bio-source of silica: preparation and characterization of PLA-silica bio-composites. RSC Advances, 4(97), 54703-54712. http://dx.doi.org/10.1039/C4RA05991C.

18. Pongdong, W., Kummerlöwe, C., Vennemann, N., Thitithammawong, A., \& Nakason, C. (2016). Property correlations for dynamically cured rice husk ash filled epoxidized natural rubber/thermoplastic polyurethane blends: influences of RHA loading. Polymer Testing, 53, 245-256. http://dx.doi. org/10.1016/j.polymertesting.2016.05.026.

19. Yswarya, E. P., Vidya Francis, K. F., Renju, V. S., \& Thachil, E. T. (2012). Rice husk ash: a valuable reinforcement for high density polyethylene. Materials \& Design, 41, 1-7. http:// dx.doi.org/10.1016/j.matdes.2012.04.035.

20. Ismail, H., Mega, L., \& Khalil, H. P. S. A. (2001). Effect of a silane coupling agent on the properties of white rice husk ash-polypropylene/natural rubber composites. Polymer International, 50(5), 606-611. http://dx.doi.org/10.1002/pi.673.

21. Santos, R. J. D., Agostini, D. L. D. S., Cabrera, F. C., Reis, E. A. P. D., Ruiz, M. R., Budemberg, E. R., Teixeira, S. R., \& Job, A. E. (2014). Sugarcane bagasse ash: new filler to natural rubber composite. Polímeros: Ciência e Tecnologia, 24(6), 646-653. http://dx.doi.org/10.1590/0104-1428.1547.

22. Ren, F., Ren, P. G., Di, Y. Y., Chen, D. M., \& Liu, G. G. (2011). Thermal, mechanical and electrical properties of linear low-density polyethylene composites filled with different dimensional SiC particles. Polymer-Plastics Technology and Engineering, 50(8), 791-796. http://dx.doi.org/10.1080/0360 2559.2011.551967.

23. Sousa, A. M. F. D., Peres, A. C. D. C., Furtado, C. R. G., \& Visconte, L. L. Y. (2017). Mixing process influence on thermal and rheological properties of NBR/SiO2 from rice husk ash. Polímeros: Ciência e Tecnologia, 27(2), 93-99. http://dx.doi. org/10.1590/0104-1428.1959.

24. Pardo, S. G., Bernal, C., Abad, M. J., Cano, J., \& Barral Losada, L. (2009). Deformation and fracture behavior of PP/ ash composites. Composite Interfaces, 16(2-3), 97-114. http:// dx.doi.org/10.1163/156855408X402830.

25. Mantovani, G. A., Oliveira, J. H. D., Santos, A. D., Rinaldi, A. W., Moisés, M. P., Radovanovic, E., \& Fávaro, S. L. (2017). Mechanical recycling of tags and labels residues using sugarcane bagasse ash. Polímeros: Ciência e Tecnologia, 27(1), 8-15. http://dx.doi.org/10.1590/0104-1428.2278.

26. Igarza, E., Pardo, S. G., Abad, M. J., Cano, J., Galante, M. J., Pettarin, V., \& Bernal, C. (2014). Structure-fracture properties relationship for Polypropylene reinforced with fly ash with and without maleic anhydride functionalized isotactic Polypropylene as coupling agent. Materials \& Design, 55, 85-92. http://dx.doi. org/10.1016/j.matdes.2013.09.055.

27. Caicedo, C., Crespo-Delgado, L. M., De La Cruz-Rodríguez, H., \& Álvarez-Jaramillo, N. A. (2017). Propiedades termomecánicas del Polipropileno: efectos durante el reprocesamiento. Ingeniería, Investigación y Tecnología, 18(3), 245-252. http:// dx.doi.org/10.22201/fi.25940732e.2017.18n3.022.

Received: Mar. 14, 2018

Revised: May 23, 2018

Accepted: May 28, 2018 